\title{
Influence of Atomic Size Factors on the Phase Stability of Laves Phase in Nb-Cr-Ni-Al and Nb-V-Ni-Al Phase Diagrams
}

\author{
Takuya Yamanouchi ${ }^{1, * 1}$ and Seiji Miura ${ }^{2, * 2}$ \\ ${ }^{1}$ Graduate School of Materials Science and Engineering, Hokkaido University, Japan \\ ${ }^{2}$ Division of Materials Science and Engineering, Faculty of Engineering, Hokkaido University, Sapporo 060-8628, Japan
}

\begin{abstract}
Phase equilibria among the refractory bcc solid solution $\left(\mathrm{bcc}_{\mathrm{ss}}\right)$, B2, and Laves phases in $\mathrm{Nb}-\mathrm{Cr}-\mathrm{NiAl}$ and $\mathrm{Nb}-\mathrm{V}-\mathrm{NiAl}$ isothermal sections were studied with the aim of introducing the NiAl-B2 phase and/or Al-containing Laves phase for improvement of the oxidation resistance of the $\mathrm{bcc}_{\mathrm{ss}}$ phase as an $\mathrm{Al}$ reservoir layer for the $\mathrm{Al}_{2} \mathrm{O}_{3}$ surface layer. Laves phases appear in a wide composition range in both of the isothermal sections, which prevent equilibration of NiAl-B2 with the Nb-rich bcc ss phase. The geometrical model proposed by Edwards was applied to understand the site-substitution behavior of the multi-component $\mathrm{AB}_{2}$ Laves phase. In the $\mathrm{Nb}-\mathrm{Cr}-\mathrm{NiAl}, \mathrm{Nb}-\mathrm{V}-\mathrm{NiAl}$, and $\mathrm{Nb}-\mathrm{Mo}-$ $\mathrm{NiAl}$ systems, the site-substitution behavior of the Laves phases could be explained by comparison of the average atomic diameters of NiAl-B2, Cr, V, and Mo. [doi:10.2320/matertrans.MJ201604]
\end{abstract}

(Received September 14, 2017; Accepted September 19, 2017; Published December 22, 2017)

Keywords: phase equilibrium, quasi-ternary phase diagram, size factor

\section{Introduction}

Nb-based alloys are the most attractive refractory materials due to their high melting temperature and low density; however, they suffer from degradation by oxidation at high temperatures. ${ }^{1,2)}$ Niobium oxide scale is non-protective because the scale is composed of equilibrium phase, $\beta-\mathrm{Nb}_{2} \mathrm{O}_{5}$, which is porous and can easily cause cracking. ${ }^{3)}$ A number of studies have been conducted toward improvement of the oxidation resistance of $\mathrm{Nb}$-based alloys. For example, $\mathrm{Nb}$ based alloys composed of silicide phases such as $\mathrm{Nb}_{5} \mathrm{Si}_{3}$ and $\mathrm{NbSi}_{2}$ or Laves phases have progressed in terms of oxidation resistance to some extent with $\mathrm{SiO}_{2}$-based coating; however, they have been reported to have insufficient oxidation resistance for practical application at operation temperatures above $1473 \mathrm{~K}^{2,4)} \mathrm{B} 2$ aluminide phases such as NiAl have also been investigated as coatings for $\mathrm{Nb}$-based alloys. They have been used as Al reservoir layers to maintain the $\mathrm{Al}_{2} \mathrm{O}_{3}$ surface layer in Ni-based superalloys. Similarly, some Lave phases containing $\mathrm{Al}$ are reported to enhance the oxidation resistance of NiAl-based alloys. ${ }^{7)}$ However, the formation of a brittle secondary reaction zone (SRZ) between $\mathrm{Nb}$-based alloys and the $\mathrm{NiAl}$ layer has been observed, which may result in degradation of the components by spallation of the $\mathrm{Al}$ reservoir layer. This is due to the appearance of various ternary phases between NiAl-B2 and the Nb-bcc solid solution in the $\mathrm{Nb}-\mathrm{Ni}-\mathrm{Al}$ ternary phase diagram. ${ }^{8,9)}$

The addition of elements to a bcc solid solution is one method to suppress formation of the SRZ. We have conducted a broad survey of X-Ni-Al (X: refractory elements) ternary systems, and several Ta-Ni-Al ternary phases are found between the Ta-bcc solid solution $\left(\mathrm{bcc}_{\mathrm{ss}}\right)$ and NiAl-B2 phase, while a $\mathrm{bcc}_{\mathrm{ss}} / \mathrm{NiAl}-\mathrm{B} 2$ two-phase field appears in the ternary $\mathrm{X}-\mathrm{Ni}-\mathrm{Al}(\mathrm{X}=\mathrm{V}, \mathrm{Cr}, \mathrm{Mo}$, and $\mathrm{W})$ systems. ${ }^{10-12)} \mathrm{C} 14$ Laves phases with a wide composition range commonly appear in the Nb-Ni-Al and Ta-Ni-Al ternary phase diagrams,

\footnotetext{
${ }^{* 1}$ Graduate Student, Hokkaido University, Japan

${ }^{* 2}$ Corresponding author, E-mail: miura@eng.hokudai.ac.jp
}

and such a ternary Laves phase is a candidate for the brittle SRZ. Therefore, it can be expected that the addition of some elements such as $\mathrm{V}, \mathrm{Cr}$, Mo, or $\mathrm{W}$ to the $\mathrm{Nb}-\mathrm{Ni}$-Al system would suppress the formation of Laves phases. Among the quaternary systems composed of $\mathrm{Ni}$ and $\mathrm{Al}$ with refractory elements ( $\mathrm{V}, \mathrm{Cr}, \mathrm{Mo}$, and $\mathrm{W}$ ) together with $\mathrm{Nb}$ or Ta, equilibrium of the bcc $_{\mathrm{ss}} / \mathrm{B} 2 /$ Laves phase in quasi-ternary Ta-CrNiAl, Ta-V-NiAl, Ta-Mo-NiAl, and Nb-Mo-NiAl sections have been reported (Fig. 1). ${ }^{13-16)}$ It is suggested that $\mathrm{Ta}(\mathrm{Ni}, \mathrm{Al})_{2}-\mathrm{C} 14$ and $\mathrm{TaCr}_{2}$ seem to be a continuous solid solution in the Ta-Cr-NiAl system (Fig. 1(a)), and in the sections of $\mathrm{Ta}-\mathrm{V}-\mathrm{NiAl}$, the solubility of $\mathrm{V}$ in the $\mathrm{Ta}(\mathrm{Ni}, \mathrm{Al})_{2}$ Laves phase is quite large (Fig. 1(b)). These wide solubility ranges of Laves phases result in narrow $\mathrm{bcc}_{\mathrm{ss}} / \mathrm{B} 2$ two-phase fields that are limited to be almost along $\mathrm{X}-\mathrm{NiAl}(\mathrm{X}=\mathrm{V}$ and $\mathrm{Cr}$ ) lines. On the other hand, in the sections of Ta-Mo-NiAl
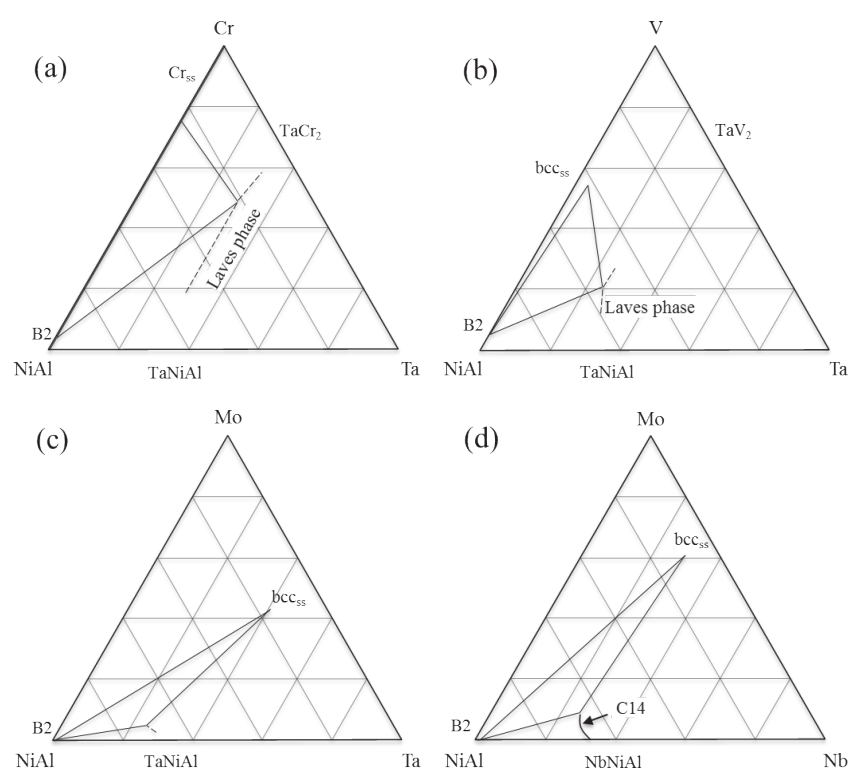

Fig. $1 \mathrm{bcc}_{\mathrm{ss}} / \mathrm{B} 2 /$ Laves three-phase fields in quasi-ternary phase diagrams of the (a) $\mathrm{Ta}-\mathrm{Cr}-\mathrm{NiAl},{ }^{13)}$ (b) Ta-V-NiAl, ${ }^{14)}$ (c) Ta-Mo-NiAl, ${ }^{15}$ and (d) $\mathrm{Nb}-\mathrm{Mo}-\mathrm{NiAl}^{16)}$ systems. 
and Nb-Mo-NiAl quasi-ternary systems (Figs. 1(c) and (d)), the limited substitution of Mo for $\mathrm{Ta}$ in $\mathrm{Ta}(\mathrm{Ni}, \mathrm{Al})_{2}-\mathrm{C} 14$ and for $\mathrm{Nb}$ in $\mathrm{Nb}(\mathrm{Ni}, \mathrm{Al})_{2}-\mathrm{C} 14$ results in wide $\mathrm{bcc}_{\mathrm{ss}} / \mathrm{NiAl}-\mathrm{B} 2$ two-phase fields. These quasi-ternary sections composed of $\mathrm{Ni}$ and $\mathrm{Al}$ with refractory elements commonly include a $\mathrm{bcc}_{\mathrm{ss}} / \mathrm{B} 2 /$ Laves three-phase field, which suggests that the site-substitution behavior and solubility range of the Laves phase region governs the extent of the $\mathrm{bcc}_{\mathrm{ss}} / \mathrm{NiAl}-\mathrm{B} 2$ twophase region. Schematics of the phase equilibria among the $\mathrm{bcc}_{\mathrm{ss}}, \mathrm{B} 2$, and Laves phases linked to the site-substitution behavior and solubility range of Laves phase are shown in Fig. 2. Figures 2(b) and (c) are sections of A-B-NiAl described in Fig. 2(a). Figure 2(b) shows the relationship between the continuous substitution of the $\mathrm{B}$ atom for $\mathrm{Ni}$ and $\mathrm{Al}$ atoms in the Laves phase, and the limited range of the $\mathrm{bcc}_{\mathrm{ss}} / \mathrm{B} 2$ two-phase field (Ta-V-NiAl and Ta-Cr-NiAl systems). On the other hand, Fig. 2(c) shows that limited substitution of the $\mathrm{B}$ atom for an $\mathrm{A}$ atom leads to a wide $\mathrm{bcc}_{\mathrm{ss}} / \mathrm{B} 2$ two-phase field (Ta-Mo-NiAl and Nb-Mo-NiAl systems).

However, the knowledge on the solubility and site-substitution behavior of elements in ternary and quaternary Laves phases is insufficient for discussion of the phase equilibria among the $\mathrm{bcc}_{\mathrm{ss}}, \mathrm{NiAl-B} 2$, and Laves phases in Nb-based alloys. Therefore, it is expected that investigations of phase equilibria related to Laves phases in higher order systems may provide valuable information not only for the development of alloys but also for fundamental alloy chemistry.

The stability of Laves phases has been explained in terms of atomic size factor and also valence electron concentration (VEC). ${ }^{17-19)}$ In binary Laves phases, the most stable ratio of atomic diameters $\mathrm{D}_{\mathrm{A}} / \mathrm{D}_{\mathrm{B}}$ is 1.225 , determined by geometrical reasoning, and the range of the ratio is between 1.05 and 1.68. ${ }^{20)}$ The $\mathrm{NbCr}_{2}$ Laves phase with a $\mathrm{D}_{\mathrm{A}} / \mathrm{D}_{\mathrm{B}}$ ratio of 1.14 appears as a stable phase, although the $D_{A} / D_{B}$ is rather smaller than the ideal value. On the other hand, $\mathrm{NbV}_{2}$ has a
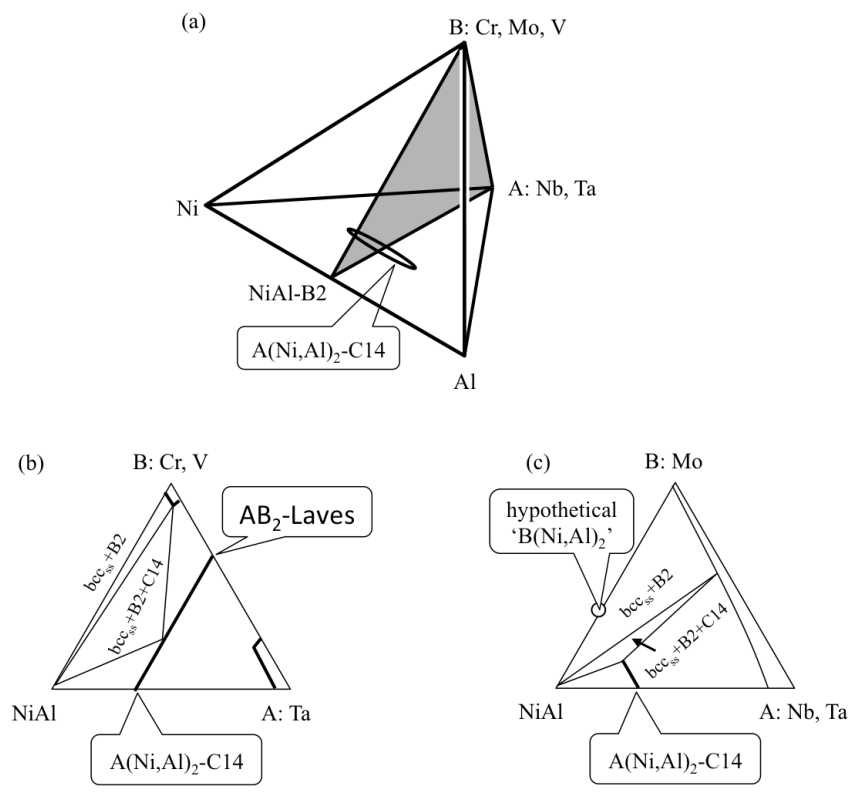

Fig. 2 Schematics of phase equilibria among the $\mathrm{bcc}_{\mathrm{ss}}, \mathrm{B} 2$, and Laves phases. (a) A-B-Ni-Al quaternary phase diagram, (b) A-B-NiAl quasiternary section with a solubility lobe of Laves phase between $\mathrm{A}(\mathrm{Ni}, \mathrm{Al})_{2}$ and $\mathrm{AB}_{2}$, and (c) A-B-NiAl quasi-ternary section with a solubility lobe of Laves phase between $\mathrm{A}(\mathrm{Ni}, \mathrm{Al})_{2}$ and hypothetical ' $\mathrm{B}(\mathrm{Ni}, \mathrm{Al})_{2}$ '. rather small $\mathrm{D}_{\mathrm{A}} / \mathrm{D}_{\mathrm{B}}$ (1.09) compared to $\mathrm{NbCr}_{2}$; therefore, $\mathrm{NbV}_{2}$ does not appear as a stable phase.

The size factor is also expected to have a large effect on the site-substitution behavior of binary Laves phases. The arguments on the site-substitution behavior are related to the introduction of constitutional vacancies. However, some experimental methods, such as the ALCHEMI method, provide direct evidence for the site-substitution behavior of elements. $^{21,22)}$ The site occupancies of $\mathrm{X}(\mathrm{X}=\mathrm{V}, \mathrm{Mo}, \mathrm{W}$, and $\mathrm{Ti})$ in the $\mathrm{NbCr}_{2}-\mathrm{C} 15$ Laves phase of $\mathrm{Nb}-\mathrm{Cr}-\mathrm{X}$ systems were investigated using the ALCHEMI method, whereby $\mathrm{V}$ tends to substitute for $\mathrm{Cr}$, while Mo, W, and $\mathrm{Ti}$ substitute for $\mathrm{Nb}^{21,22)}$ These results also confirm that the tendency of the solubility lobe is a good index to understand the site-substitution behavior in the $\mathrm{NbCr}_{2}-\mathrm{C} 15$ Laves phase. The atomic sizes of Mo, $\mathrm{W}$, and $\mathrm{Ti}$ are close to $\mathrm{Nb}$, while $\mathrm{V}$ is close to $\mathrm{Cr}$; therefore, it can be concluded that the size factor is a key to understand the site-substitution behavior of Laves phases. According to previous studies, ${ }^{9,23)}$ both $\mathrm{Ni}$ and $\mathrm{Al}$ tend to occupy the $\mathrm{B}$-site of the $\mathrm{AB}_{2}$-type Laves phases $\mathrm{Nb}(\mathrm{Ni}, \mathrm{Al})_{2}$ and $\mathrm{Ta}(\mathrm{Ni}, \mathrm{Al})_{2}$. Figure 3 shows various $\mathrm{Nb}$-based ternary systems with $\mathrm{Cr}, \mathrm{V}, \mathrm{Ni}$, or $\mathrm{Al}$. Each of these has $\mathrm{C} 14$ and/or $\mathrm{C} 15$ Laves phases. According to $\mathrm{Nb}-\mathrm{Cr}-\mathrm{Al}, \mathrm{Nb}-\mathrm{Cr}-\mathrm{Ni}$, and $\mathrm{Nb}-\mathrm{Al}-\mathrm{Ni}$ isothermal sections (Figs. 3(a)-(c)), wide compositional ranges of the $\mathrm{Nb}(\mathrm{Cr}, \mathrm{Al})_{2}$ and $\mathrm{Nb}(\mathrm{Cr}, \mathrm{Ni})_{2}$ ternary Laves phases have been identified, ${ }^{9,24,25)}$ which suggests a wide Laves phase region in the $\mathrm{Nb}-\mathrm{Cr}-\mathrm{Ni}$ - $\mathrm{Al}$ quaternary system with a chemical description of $\mathrm{Nb}(\mathrm{Cr}, \mathrm{Ni}, \mathrm{Al})_{2}$. Such $\mathrm{C} 14$ Laves phases have been identified in Ni-Al-Cr-Mo-Nb alloys, ${ }^{26,27)}$ and Zeumer and Sauthoff proposed to describe them as $\mathrm{Nb}\left(\mathrm{Cr}_{1-\mathrm{x}-\mathrm{y}} \mathrm{Ni}_{\mathrm{x}} \mathrm{Al}_{\mathrm{y}}\right)_{2}{ }^{28}{ }^{28}$ Similarly, a $\mathrm{Nb}(\mathrm{Cr}, \mathrm{Ni})_{2}$ Laves phase with $\mathrm{C} 14$ structure was observed in the $\mathrm{Ni}-\mathrm{Al}-$ Cr-Mo-Ti-Hf-Nb-W system. ${ }^{29)}$ Therefore, similar to the $\mathrm{Ta}(\mathrm{Ni}, \mathrm{Al})_{2}$ and $\mathrm{TaCr}_{2}$ Laves phases in the Ta-Ni-Al-Cr quaternary system, a continuous solid solution between $\mathrm{Nb}(\mathrm{Ni}, \mathrm{Al})_{2}$ and $\mathrm{NbCr}_{2}$ is expected. One purpose of the present study is thus to investigate the site-substitution behavior of $\mathrm{Cr}$ in the $\mathrm{Nb}(\mathrm{Ni}, \mathrm{Al})_{2}$ ternary Laves phase.

To understand the atomic size effect on the site-substitution behavior in the $\mathrm{Nb}(\mathrm{Ni}, \mathrm{Al})_{2}$ Laves phase, we have focused on $\mathrm{V}$ because its atomic size is slightly larger than $\mathrm{Cr}$. Figure 3(d) shows the site-substitution behavior of $\mathrm{V}$ in $\mathrm{NbCr}_{2}$, and strongly suggests that $\mathrm{V}$ has a tendency to substitute for $\mathrm{Cr}$ in $\mathrm{NbCr}_{2}$ because of its similar atomic size. Similar to $\mathrm{NbCr}_{2}$ with $\mathrm{Ni}$ substitution, Ni-containing $\mathrm{NbV}_{2}$, i.e., $\mathrm{Nb}(\mathrm{V}, \mathrm{Ni})_{2}$, is reported to be a stable phase. Therefore, it is expected that similar to the expected extension of the Laves phase field with $\mathrm{Cr}$ addition to the $\mathrm{Nb}-\mathrm{Ni}-\mathrm{Al}$ system, $\mathrm{V}$ addition may result in the formation of $\mathrm{Nb}(\mathrm{V}, \mathrm{Ni}, \mathrm{Al})_{2}-\mathrm{C} 14$ with a wide composition range in the $\mathrm{Nb}-\mathrm{V}-\mathrm{Ni}-\mathrm{Al}$ system, although there is no information on the ternary Laves phases in the $\mathrm{Nb}-\mathrm{V}$-Al system. A comparison of the site-substitution behavior of $\mathrm{V}$ and $\mathrm{Cr}$ in the $\mathrm{Nb}(\mathrm{Ni}, \mathrm{Al})_{2}$ ternary Laves phase is thus a good example to understand and expand the atomic size effect on the stability of Laves phases.

Despite the above expectations, the site-substitution behavior of Laves phases composed of several elements including $\mathrm{Al}$ is not clearly understood, because the atomic diameter of $\mathrm{Al}$ evaluated from the pure $\mathrm{Al}$ structure is much larger than that of $\mathrm{Cr}, \mathrm{V}$, and $\mathrm{Ni}$. The size of the $\mathrm{Al}$ atom in 

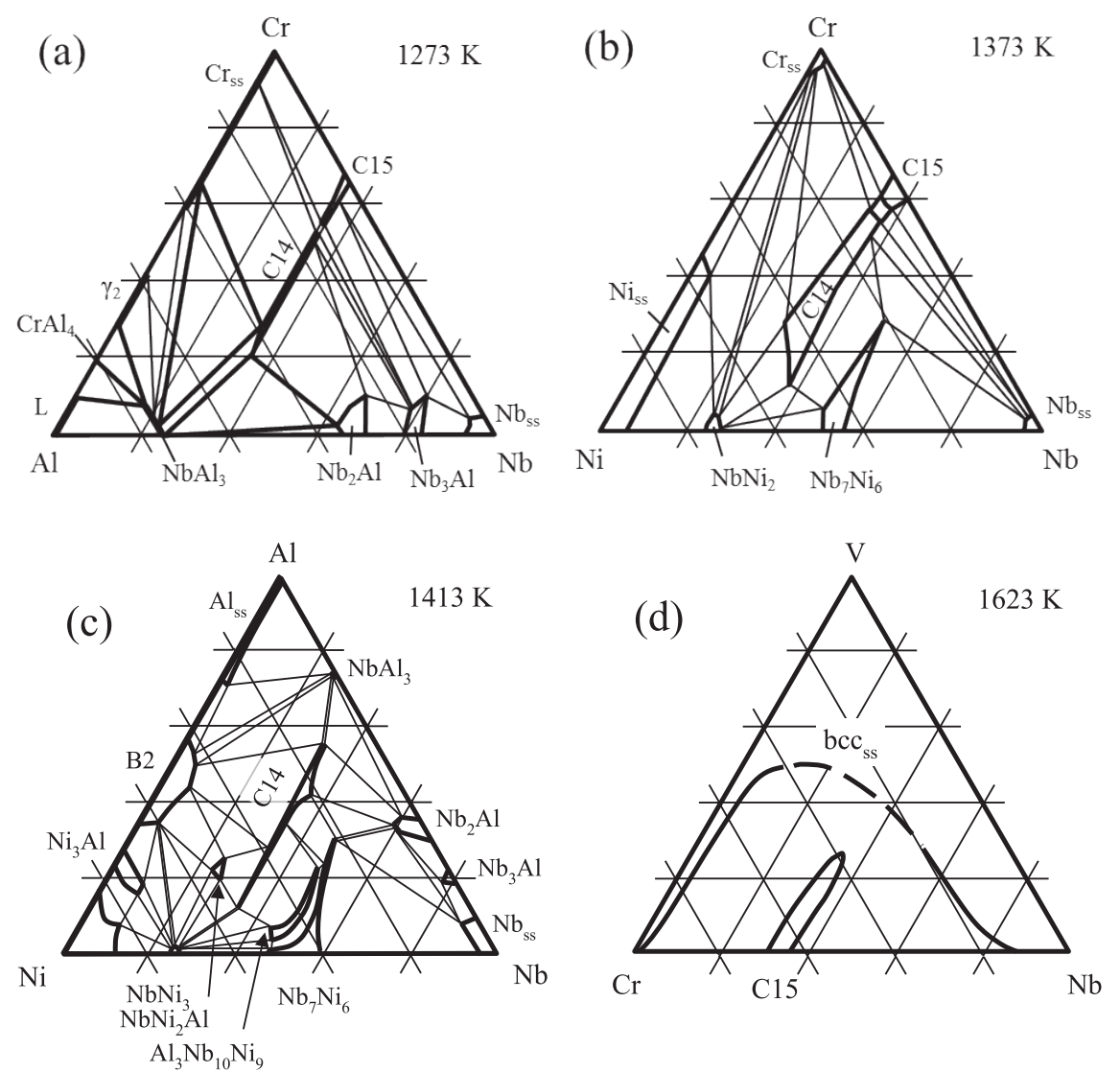

Fig. 3 Isothermal sections of the (a) Nb-Cr-Al, ${ }^{24)}$ (b) Nb-Cr-Ni, ${ }^{25)}$ (c) Nb-Ni-Al, ${ }^{9)}$ and (d) Nb-Cr- ${ }^{21)}$ systems.

some intermetallic compounds such as $\mathrm{Ni}_{3} \mathrm{Al}$ and $\mathrm{NiAl}$ is smaller than that of pure $\mathrm{Al}^{30}$ ) Therefore, in the present study, phase equilibria among $\mathrm{bcc}_{\mathrm{ss}}, \mathrm{B} 2$, and Laves phases in the $\mathrm{Nb}-\mathrm{Cr}-\mathrm{NiAl}$ and $\mathrm{Nb}-\mathrm{V}-\mathrm{NiAl}$ systems were investigated as good examples to understand not only the site-substitution behavior of $\mathrm{Cr}$ and $\mathrm{V}$ but also the site-substitution behavior of $\mathrm{Al}$ in Laves phase together with a transition metal element $(\mathrm{Ni})$ by combining the direction and extent of solubility lobes in terms of the atomic diameter. The model proposed by Edwards is applied to understand the effect of the atomic size factor on the stability of Laves phase with $\mathrm{Al}^{31)}$ Although Laves phases are commonly brittle at room temperature, Anton et al. ${ }^{32)}$ concluded that materials based on the $\mathrm{C} 14 / \mathrm{C} 15$ Laves phases, such as $\mathrm{NbCr}_{2}$ and $\mathrm{TaCr}_{2}$, are potential candidates for high-temperature structural applications in the temperature range above $1273 \mathrm{~K}$ because of their high melting points. There have been various investigations on multiphase in-situ composites including Laves phases with the NiAl-B2 phase, ${ }^{33)}$ however, the position of formation, size, and shape of Laves phases must be appropriately controlled to avoid brittle fracture of the materials. The results obtained through this study are expected to contribute to control of the Laves phase, and assist determination of whether to include or exclude them from materials composed of the bcc $\mathrm{ss}_{\mathrm{ss}}$ and $\mathrm{B} 2$ aluminides.

\section{Experimental Procedures}

The nominal compositions of the alloys employed are listed in Table 1. To obtain $\mathrm{Nb}-\mathrm{X}-\mathrm{NiAl}(\mathrm{X}=\mathrm{Cr}$ and $\mathrm{V})$ iso-
Table 1 Nominal compositions of the alloys employed (at $\%$ ).

\begin{tabular}{cccccc}
\hline Alloy No. & $\mathrm{Nb}$ & $\mathrm{Cr}$ & $\mathrm{V}$ & $\mathrm{Ni}$ & $\mathrm{Al}$ \\
\hline 1 & 20 & 24 & & 28 & 28 \\
\hline 2 & 20 & 10 & & 35 & 35 \\
\hline 3 & 22.5 & & 7.5 & 35 & 35 \\
\hline 4 & 7.5 & & 22.5 & 35 & 35 \\
\hline
\end{tabular}

thermal sections, the nominal $\mathrm{Ni}$ composition was kept the same as the nominal $\mathrm{Al}$ composition. Alloys were prepared from high-purity raw materials $(99.99 \% \mathrm{Ni}, 99.99 \% \mathrm{Al}$, $99.99 \% \mathrm{Cr}, 99.5 \% \mathrm{~V}, 99.9 \% \mathrm{Nb}$ ) by arc-melting repeated at least ten times with a non-consumable $\mathrm{W}$ electrode on a water-cooled copper hearth in an Ar atmosphere to ensure chemical homogeneity. Alloy ingots of ca. $20 \mathrm{~g}$ were cut using a wheel cutter, and some of the ingots were sealed in evacuated silica tubes for heat-treatment at $1473 \mathrm{~K}$ for $168 \mathrm{~h}$, followed by water quenching. X-ray diffraction (XRD) analysis was conducted to identify the phases in the alloys. Microstructural observations and wave-length dispersive spectroscopy (WDS) for compositional analysis of the equilibrium phases in each sample were performed using field emission-scanning electron microscopy (FE-SEM; JEOL, JXA-8530F) equipped with electron probe microanalysis (EPMA). It is generally difficult to determine the composition of phases with grain sizes less than the spatial resolution of the WDS instrumentation, which is typically ca. $1 \mu \mathrm{m}$. Therefore, to overcome this problem, WDS multipoint analyses were conducted. In this method, the typical 
number of points for WDS point analysis was 100 points. These data obtained from three-phase alloys are either on the tie-line or within the tie-triangle in the ternary phase diagram. Therefore, multi-point analysis on multi-phase alloys is a powerful method to obtain $\alpha-\beta-\gamma$ tie-triangles for $\alpha / \beta / \gamma$ three-phase equilibrium of alloys with fine microstructure, and the data set allows the composition of the equilibrium phase to be deduced by application of the phase rule. This method was applied to some of the alloys with fine microstructure. ${ }^{34)}$

\section{Results}

Figure 4 shows typical microstructures of $\mathrm{Nb}-\mathrm{Cr}-\mathrm{Ni}-\mathrm{Al}$ and $\mathrm{Nb}-\mathrm{V}-\mathrm{Ni}-\mathrm{Al}$ alloys, and the results of WDS multi-point analysis performed on the alloys are shown in Fig. 5 as isothermal sections of the quasi-ternary phase diagrams of $\mathrm{Nb}$ $\mathrm{Cr}-\mathrm{NiAl}$ and $\mathrm{Nb}-\mathrm{V}-\mathrm{NiAl}$ at $1473 \mathrm{~K}$. In the Nb-Cr-Ni-Al alloys shown in Figs. 4(a) and (b), the $\mathrm{Cr}-\mathrm{bcc}_{\mathrm{ss}}$ phase (gray area), NiAl-B2 phase (dark area), and $\mathrm{Nb}(\mathrm{Cr}, \mathrm{Ni}, \mathrm{Al})_{2}-\mathrm{C} 14$
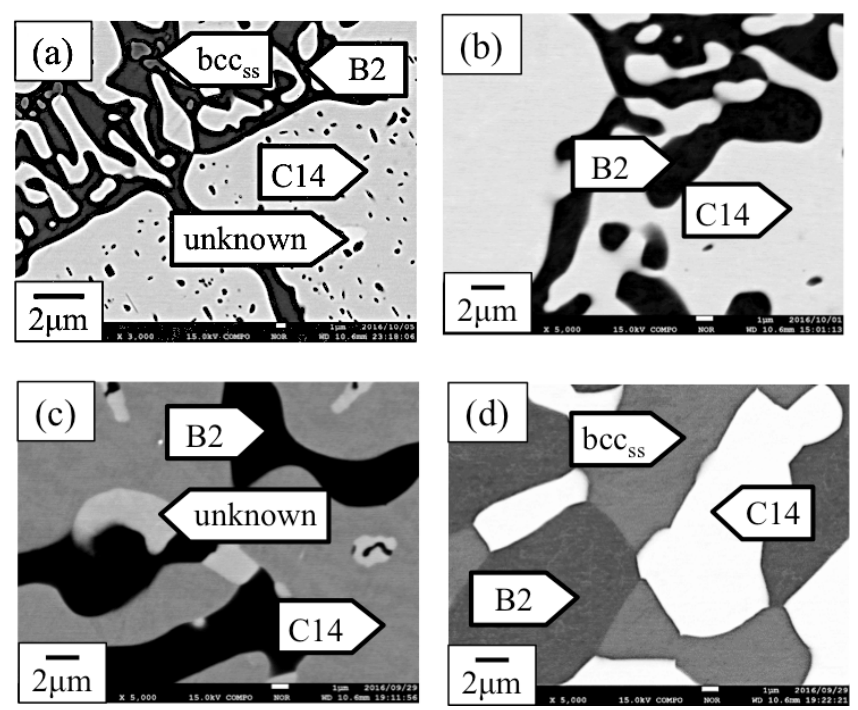

Fig. 4 Microstructures of alloys after heat-treatment at $1473 \mathrm{~K}$ for 168 hours. (a) \#1 Nb-24Cr-28Ni-28Al, (b) \#2 Nb-10Cr-35Ni-35Al, (c) \#3 $\mathrm{Nb}-7.5 \mathrm{~V}-35 \mathrm{Ni}-35 \mathrm{Al}$, and (d) \#4 Nb-22.5V-35Ni-35Al. phase (bright area) were confirmed by combining compositional analysis and XRD analysis results. An unknown phase (white area) was also identified. In the $\mathrm{Nb}-\mathrm{V}-\mathrm{Ni}-\mathrm{Al}$ alloys

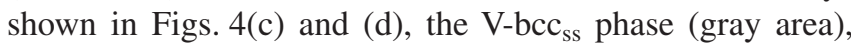
NiAl-B2 phase (dark area), C14 phase (bright area), and unknown phases (white area) were confirmed. In the $\mathrm{Nb}-\mathrm{Ni}-\mathrm{Al}$ phase diagram, the $\mathrm{Nb}_{7} \mathrm{Ni}_{6}$ phase is reported to exhibit large Al solubility, with as high as 30.3 at\% substitution for $\mathrm{Ni}$ (Fig. 3(c)). ${ }^{9)}$ The composition range of the $\mathrm{Nb}_{7} \mathrm{Ni}_{6}$ phase extends to $50 \mathrm{at} \% \mathrm{Nb}$ in the $\mathrm{Nb}-\mathrm{Ni}$ binary system, and the composition in the $\mathrm{Nb}-\mathrm{Ni}-\mathrm{Al}$ ternary system $(46 \mathrm{Nb}-24 \mathrm{Ni}-$ $30 \mathrm{Al}$ ) also extends to $\mathrm{Nb}$ compositions lower than stoichiometry and which are close to the unknown phase $(45 \mathrm{Nb}$ $3 \mathrm{~V}-20 \mathrm{Ni}-32 \mathrm{Al}$ in at\%) in alloy \#3. Therefore, the unknown phase is probably $\mathrm{Nb}_{7} \mathrm{Ni}_{6}\left(\mathrm{~W}_{6} \mathrm{Fe}_{7}\right.$-type structure) phase based on consideration of the composition of the unknown phase.

In Fig. 5, closed symbols denote the nominal compositions of alloys and open symbols denote results from WDS multi-point analysis. WDS multi-point analyses performed on the alloys provided information on the tie-lines between two-phase or three-phase equilibria within the tie-triangle. In Fig. 5(a), a single phase region of Laves phase lies along the line connecting $\mathrm{Nb}(\mathrm{Ni}, \mathrm{Al})_{2}$ and $\mathrm{NbCr}_{2}$ in the $\mathrm{Nb}-\mathrm{Cr}-\mathrm{NiAl}$ system, which results in the $\mathrm{Nb}(\mathrm{Cr}, \mathrm{Ni}, \mathrm{Al})_{2}$ quaternary Laves phase. The $\mathrm{Nb}$ composition of the $\mathrm{Nb}$-lean side of the $\mathrm{C} 14$ phase is almost constant at ca. 30 at\%. This value is consistent with the off-stoichiometric (Nb-lean) composition of binary $\mathrm{NbCr}_{2}-\mathrm{C} 15(31.5 \mathrm{at} \% \mathrm{Nb})$, which has anti-site substitution of $\mathrm{Cr}^{35,36)}$ The $\mathrm{NiAl} /$ bcc two-phase equilibrium was determined to appear only around the $\mathrm{NiAl} / \mathrm{Cr}$ edge with quite a small amount of $\mathrm{Nb}$ in the bcc phase.

In Fig. 5(b), the single phase region of Laves phase in the $\mathrm{Nb}-\mathrm{V}-\mathrm{NiAl}$ system also seems to extend along a line connecting $\mathrm{Nb}(\mathrm{Ni}, \mathrm{Al})_{2}$ and hypothetical " $\mathrm{NbV}_{2}$ ", which results in the $\mathrm{Nb}(\mathrm{V}, \mathrm{Ni}, \mathrm{Al})_{2}$ quaternary Laves phase. However, the compositional region of the Laves phase deviates slightly toward the $\mathrm{V}$ corner. This tendency is similar with that for $\mathrm{Ta}(\mathrm{Ni}, \mathrm{Al})_{2}-\mathrm{C} 14$ in the $\mathrm{Ta}-\mathrm{V}-\mathrm{NiAl}$ system. The $\mathrm{NiAl} /$ bcc two-phase equilibrium also appears only around the $\mathrm{NiAl} / \mathrm{V}$ edge with a small amount of $\mathrm{Nb}$ in the bcc phase. (a)

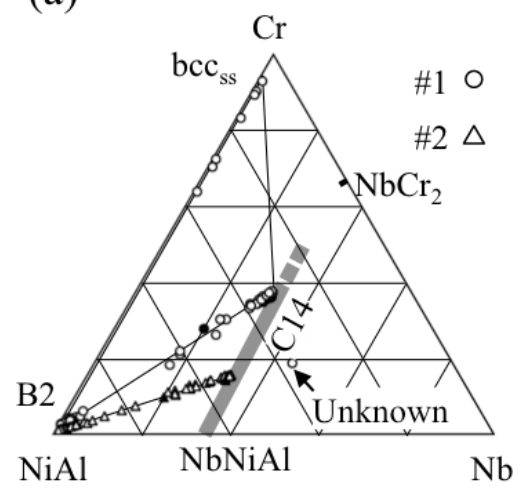

(b)

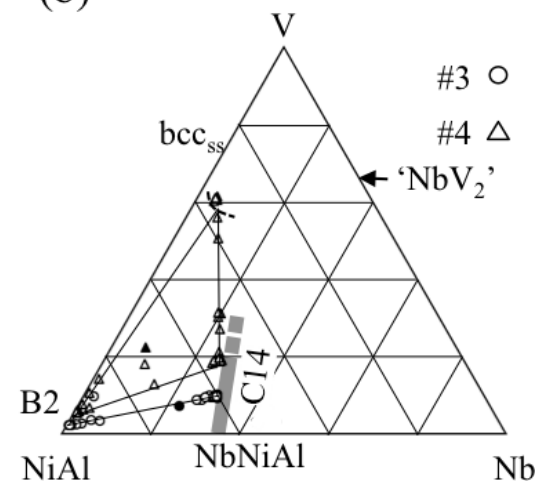

Fig. 5 Compositional analysis results for (a) Nb-Cr-NiAl alloys after heat-treatment at $1473 \mathrm{~K}$, and (b) Nb-V-NiAl alloys after heat-treatment at $1473 \mathrm{~K}$. Alloy compositions are represented by closed symbols. The composition of the unknown phase in the $\mathrm{Nb}-\mathrm{V}-\mathrm{Ni}-\mathrm{Al}$ alloy is not on the section of $\mathrm{Nb}-\mathrm{V}-\mathrm{NiAl}$. 


\section{Discussion}

The NiAl/bcc two-phase equilibrium appears only around the $\mathrm{NiAl} / \mathrm{Cr}$ edge in the $\mathrm{Nb}-\mathrm{Cr}-\mathrm{NiAl}$ system and also around the $\mathrm{NiAl} / \mathrm{V}$ edge in the $\mathrm{Nb}-\mathrm{V}-\mathrm{NiAl}$ system. The $\mathrm{NiAl} /$ bcc phase equilibria in these quaternary systems are limited by the extended solubility lobe of the $\mathrm{Nb}(\mathrm{NiAl})_{2}-\mathrm{C} 14$ Laves phase with $\mathrm{Cr}$ and $\mathrm{V}$ substitution. The direction of the solubility lobes of the $\mathrm{C} 14$ phase in the $\mathrm{Nb}-\mathrm{Cr}-\mathrm{NiAl}$ and $\mathrm{Nb}-\mathrm{V}$ $\mathrm{NiAl}$ systems indicates that the preferential site of $\mathrm{Ni}, \mathrm{Cr}, \mathrm{V}$, and $\mathrm{Al}$ is the $\mathrm{B}$-site of the $\mathrm{AB}_{2}$ Laves phase in these quaternary systems. This is consistent with the $\mathrm{Ni}$ and $\mathrm{Al}$ occupation of B-sites in the $\mathrm{C} 14$ phase $^{37)}$ of the $\mathrm{Nb}-\mathrm{Ni}$-Al ternary system and the preferential occupation of B-sites in the Laves phase by $\mathrm{V}$ and $\mathrm{Cr}$ in the $\mathrm{Nb}-\mathrm{Cr}-\mathrm{V}$ ternary system. $^{21,22)}$

To reveal the contribution of the atomic diameter ratio to the stability in the multi-component Laves phases, the average atomic diameters of $\mathrm{A}$ and $\mathrm{B}$ atoms must be estimated. The atomic sizes proposed by Goldschmidt have been traditionally used to examine the effect of atomic size on various aspects, such as Vegard's law for lattice constants and the stability of phases. Table 2 shows Goldschmidt diameters (coordination number $(\mathrm{C} . \mathrm{N})=$.12 ) for each element $\mathrm{D}_{\mathrm{C} . \mathrm{N} .12}$, which are equal to twice the Goldschmidt radii $\left(\mathrm{D}_{\mathrm{C} . \mathrm{N} .12}=\right.$ $2 R_{\text {C.N.12) }}$ based on the size evaluated from the crystal structure and lattice constant(s) of the pure elements, together with the occupancy site in the $\mathrm{NbCr}_{2}$ Laves phase. The order of $\mathrm{D}_{\mathrm{C} . \mathrm{N} .12}$ seems to be strongly related to the occupancy; however, $\mathrm{Al}$ occupies $\mathrm{Cr}$ sites. The Goldschmidt diameter of
$\mathrm{Al}$ is estimated to be close to that for $\mathrm{Nb}$ and larger than that for Mo. According to an isothermal section of the Nb-MoNiAl system, Mo tends to occupy A-sites, although its diameter is smaller than $\mathrm{Al}$, which prefers to occupy B-sites. These experimental observations indicate that there is no simple relationship between the Goldschmidt diameters and the site-substitution behavior of $\mathrm{Al}$ in the Laves phase. Edwards has pointed out the importance of the geometrical feature of Laves phases with site occupancy of the elements, and concluded that bcc metals tend to occupy A-sites, while fcc or hcp metals tend to occupy B-sites. ${ }^{31)}$ Thus, this rule seems to justify the occupancy of $\mathrm{Al}$ at $\mathrm{B}$-sites in a number of Laves phases, although the Goldschmidt diameter of $\mathrm{Al}$ is large. However, bcc metals such as $\mathrm{Cr}$ and $\mathrm{V}$ substitute for $\mathrm{B}$-site elements if the atomic diameters of the A-site elements are much larger than $\mathrm{Cr}$ or $\mathrm{V}$.

To overcome this inconsistency, we should take into account that the size of $\mathrm{Al}$ atoms in some intermetallic compounds such as $\mathrm{Ni}_{3} \mathrm{Al}$ and $\mathrm{NiAl}$ have been evaluated to be smaller than that of pure $\mathrm{Al}^{30}{ }^{30}$ Figure 6 shows the Al concentration dependence of the average atomic volumes of $\mathrm{Ni}-\mathrm{Al}$ alloys and $\mathrm{Nb}(\mathrm{Ni}, \mathrm{Al})_{2}$ Laves phase. Figure 6(a) shows a way to evaluate the atomic volume of $\mathrm{Al}$ in the $\mathrm{Ni}$ solid

Table 2 Goldschmidt diameters $\mathrm{D}_{\mathrm{C} . \mathrm{N} .12}$ of elements, ${ }^{39)}$ together with the occupancy site in the $\mathrm{NbCr}_{2} \mathrm{AB}_{2}$-Laves phase.

\begin{tabular}{lccccccc} 
& $\mathrm{Ni}$ & $\mathrm{Cr}$ & $\mathrm{V}$ & $\mathrm{Mo}$ & $\mathrm{Al}$ & $\mathrm{Nb}$ & $\mathrm{Ta}$ \\
\hline $\mathrm{D}_{\text {C.N.12 }}[\mathrm{nm}]$ & 0.249 & 0.257 & 0.270 & 0.280 & 0.286 & 0.294 & 0.294 \\
Occupancy site & B-site & B-site & B-site & A-site & B-site & A-site & A-site
\end{tabular}

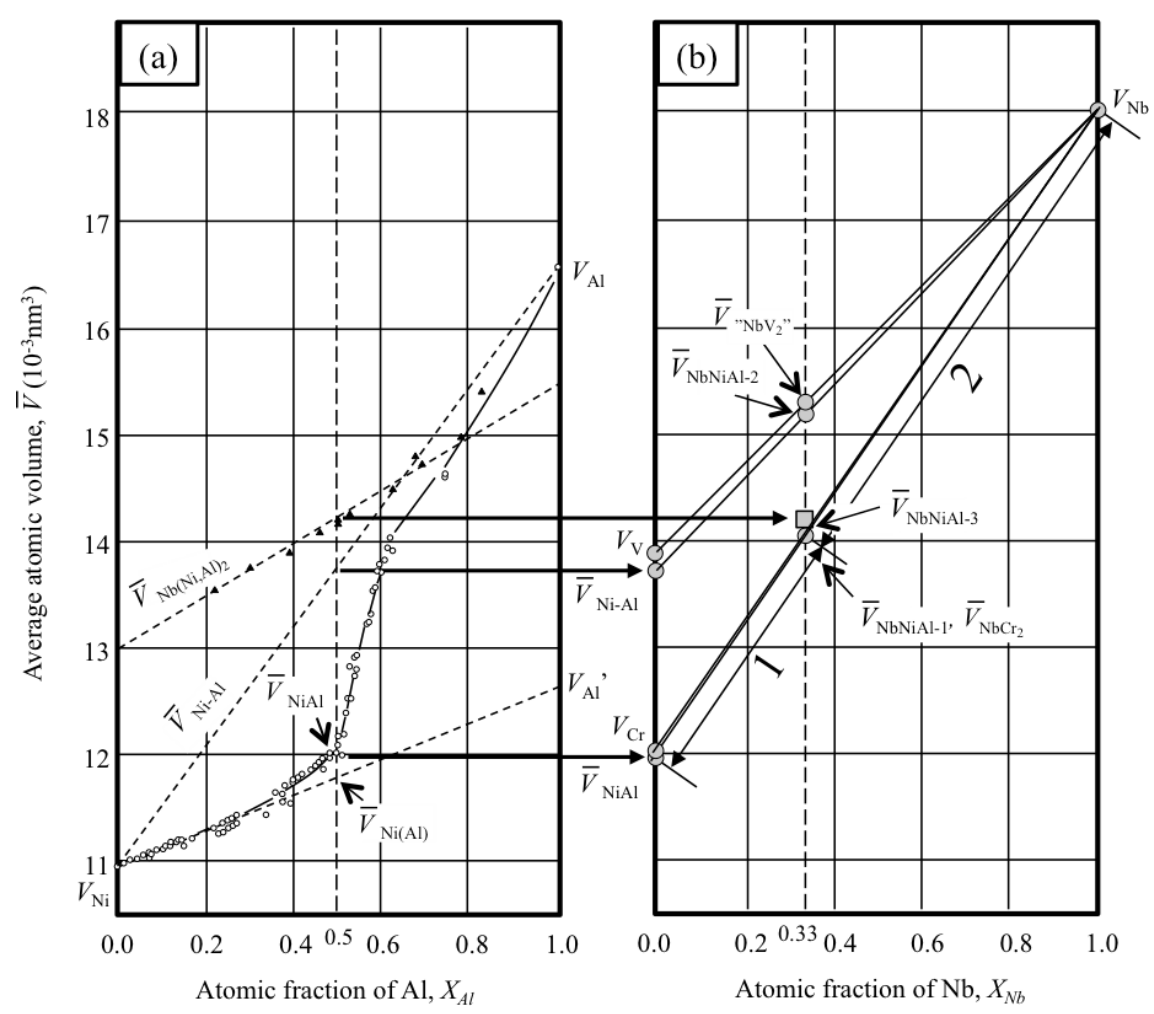

Fig. 6 Average atomic volumes $(\bar{V})$ of phases as a function of the atomic fraction of $\mathrm{Al}$ in the alloy composition. (a) Open circles: average atomic volumes of phases in the Ni-Al binary system, $\bar{V}_{\mathrm{Ni}-\mathrm{Al}}{ }^{30)}$; closed triangles: average atomic volumes of the $\mathrm{Nb}(\mathrm{Ni}, \mathrm{Al})_{2}-\mathrm{C} 14 \mathrm{phase}$ in the $\mathrm{Nb}-\mathrm{Ni}-\mathrm{Al}$ ternary system,

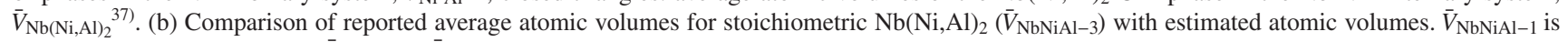
a weighted average of $V_{\mathrm{Nb}}$ and $\bar{V}_{\mathrm{NiAl}}$, and $\bar{V}_{\mathrm{NbNiAl}-2}$ is an average of $V_{\mathrm{Nb}}, V_{\mathrm{Ni}}$, and $V_{\mathrm{Al}}$. 
solution $\mathrm{V}_{\mathrm{Al}}$ by extrapolating the line for $\mathrm{Ni}$-rich $\mathrm{Ni}_{1-\mathrm{x}} \mathrm{Al}_{\mathrm{x}}$ to $\mathrm{Al}=100$ at $\%$. It is clear that $\mathrm{V}_{\mathrm{Al}}$ is smaller than that of pure $\mathrm{Al}, \mathrm{V}_{\mathrm{Al}}$. A considerable lattice contraction of $\mathrm{Al}$ has also been reported in fcc alloys, as shown in Table $33^{30,38)}$ therefore, careful discussion is required to determine the atomic diameter of $\mathrm{Al}$ in alloys and compounds. In this study, $\mathrm{Ni}$ and $\mathrm{Al}$ in the $\mathrm{Nb}(\mathrm{Cr}, \mathrm{Ni}, \mathrm{Al})_{2}$ or $\mathrm{Nb}(\mathrm{V}, \mathrm{Ni}, \mathrm{Al})_{2}$ Laves phases are almost equiatomic and these elements occupy $2 \mathrm{a}$ and $6 \mathrm{~h}$ sites with equal probability in stoichiometric $\mathrm{Nb}(\mathrm{Ni}, \mathrm{Al})_{2}{ }^{37)}$; therefore, the average atomic diameter of $\mathrm{Ni}$ and $\mathrm{Al}$ is meaningful to examine the size factor effect on the stability of the Laves phases.

In Fig. 6 , the average atomic volume $\overline{\mathrm{V}}_{\mathrm{Ni}(\mathrm{Al})}$, estimated from the extrapolated line of the Ni solid solution (C.N. 12) at $\mathrm{Al}=50$ at $\%$ is $11.8 \times 10^{-3} \mathrm{~nm}^{3}$ (average atomic diameter

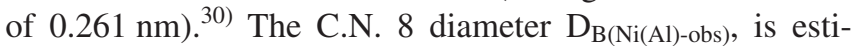
mated by dividing the C.N. 12 average atomic diameter by 1.03 , which is a widely accepted factor for the conversion of $\mathrm{D}$ (C.N. 12) to $\mathrm{D}($ C.N. 8) based on the hypothesis that atomic volume does not change by allotropic transformation. ${ }^{31)}$ The evaluated $\mathrm{D}_{\mathrm{B} \text { (Ni(Al)-obs) }}$ (C.N. 8) is $0.261 / 1.03=0.248 \mathrm{~nm}$, which is almost the same as the average atomic diameter of $\mathrm{Ni}$ and $\mathrm{Al}$ in NiAl-B2, $\mathrm{D}_{\mathrm{B}(\mathrm{NiAl}-\mathrm{obs})}(\mathrm{C} . \mathrm{N} .8)=0.249 \mathrm{~nm}$. The reported average atomic volume of $\mathrm{Nb}(\mathrm{Ni}, \mathrm{Al})_{2}-\mathrm{C} 14$ $\overline{\mathrm{V}}_{\mathrm{NbNiAl}-3}$, is consistent with the average volume of $\overline{\mathrm{V}}_{\mathrm{NbNiAl}-1}$ estimated as a weighted average of $\mathrm{V}_{\mathrm{Nb}}$ and $\overline{\mathrm{V}}_{\mathrm{NiAl}}$, while it is smaller than the average atomic volume $\overline{\mathrm{V}}_{\mathrm{NbNiAl}-2}$, estimated from the average volumes of pure $\mathrm{Nb}$, pure $\mathrm{Ni}$, and pure $\mathrm{Al}$. Thus, $\overline{\mathrm{V}}_{\mathrm{NiAl}}$ can be justified to examine the stability of Laves phases that contain the same amount of $\mathrm{Ni}$ and $\mathrm{Al}$.

As the next step, $\mathrm{D}_{\mathrm{B}(\mathrm{X}(\mathrm{Al}) \text {-obs) }}$ (C.N. 8) and $\mathrm{D}_{\mathrm{B} \text { (XAl-obs) }}$ (C.N. 8) values in various $\mathrm{X}-\mathrm{Al}$ binary systems at $\mathrm{Al}=$ 50 at\% were estimated to examine the validity of applying the average atomic diameter estimated using the lattice constant of B2 aluminide, and are shown in Table 4 together with the estimated $\mathrm{D}_{\mathrm{B}(\mathrm{X} / \mathrm{Al}-\mathrm{obs})}$ (C.N. 8). While the difference between $\mathrm{D}_{\mathrm{B}(\mathrm{X}(\mathrm{Al}) \text {-obs) }}$ (C.N. 8) and $\mathrm{D}_{\mathrm{B}(\mathrm{X} / \mathrm{Al}-\mathrm{obs})}$ (C.N. 8) at $\mathrm{Al}=50$ at $\%$ in each binary system was larger than $0.008 \mathrm{~nm}$ (3.2\%), the difference between $\mathrm{D}_{\mathrm{B}(\mathrm{X}(\mathrm{Al}) \text {-obs) }}$ (C.N. 8) and $\mathrm{D}_{\mathrm{B} \text { (XAl-obs) }}(\mathrm{C} . \mathrm{N} .8)$ at $\mathrm{Al}=50$ at $\%$ in each binary system was within $0.003 \mathrm{~nm}(1.2 \%)$, which indicates that the average atomic diameter estimated from the average atomic volume of the fcc solid solution structure, $\mathrm{D}_{\mathrm{B}(\mathrm{X}(\mathrm{Al})-\mathrm{obs})}$ (C.N. 8), is much closer to the diameter of $\mathrm{B} 2$ aluminide $\mathrm{D}_{\mathrm{B} \text { (XAl-obs) }}$

Table 3 Atomic diameters of $\mathrm{Al}$ in alloys estimated from extrapolated atomic diameter or average atomic volume of solid solution fcc phases, in the same manner as that with Fig. 6(a).

\begin{tabular}{cc}
\hline Alloys & Extrapolated atomic diameter of $\mathrm{Al}[\mathrm{nm}]$ \\
\hline $\mathrm{Co}-\mathrm{Al}$ & $0.263^{30)}$ \\
\hline $\mathrm{Rh}-\mathrm{Al}$ & $0.269^{30)}$ \\
\hline $\mathrm{Ir}-\mathrm{Al}$ & $0.267^{30)}$ \\
\hline $\mathrm{Ni}-\mathrm{Al}$ & $0.262^{30)}$ \\
\hline $\mathrm{Pd}-\mathrm{Al}$ & $0.264^{30)}$ \\
\hline $\mathrm{Pt}-\mathrm{Al}$ & $0.264^{30)}$ \\
\hline $\mathrm{Cu}-\mathrm{Al}$ & $0.272,,^{30)} 0.271^{38)}$ \\
\hline $\mathrm{Ag}-\mathrm{Al}$ & $0.280,{ }^{30)} 0.2799-0.2808^{38)}$ \\
\hline $\mathrm{Au}-\mathrm{Al}$ & $0.277,,^{30)} 0.277^{38)}$ \\
\hline
\end{tabular}

(C.N. 8) than $\mathrm{D}_{\mathrm{B}(\mathrm{X} / \mathrm{Al} \text {-obs) }}$ (C.N. 8). This means that the contraction of $\mathrm{Al}$ in the compound and solid solution alloys are almost the same, i.e., not sensitive to the crystal structure.

Now we should try the validity of the above discussion on the existence of $\mathrm{AB}_{2}$ Laves phases composed of various combinations of pure A and XAl-B2 aluminide, or pure A and pure B. ${ }^{39-42)}$ (Table 5) Laves phases do not appear in the combination of $\mathrm{A}$ and $\mathrm{B}$ with $\mathrm{D}_{\mathrm{A}} / \mathrm{D}_{\mathrm{B}}$ smaller than 1.05. In binary Laves phases, the most stable ratio of atomic diameter $\mathrm{D}_{\mathrm{A}} / \mathrm{D}_{\mathrm{B}}$ is 1.225 and the reported ratio ranges between 1.05 and 1.68. As shown in Table $5, \mathrm{D}_{\mathrm{A}} / \mathrm{D}_{\mathrm{B}}$ among the $\mathrm{A}-(\mathrm{XAl})$ pseudo-binary systems is between 1.06 and 1.28 , which is within the range observed in binary Laves phases. On the other hand, from application of $\mathrm{D}_{\mathrm{B}}$ estimated from the average atomic volumes of the pure elements ( $\mathrm{X}$ and $\mathrm{Al}$ ) in $\mathrm{B}$-sites, $\mathrm{D}_{\mathrm{A}} / \mathrm{D}_{\mathrm{B}}$ of the $\mathrm{A}(\mathrm{X}, \mathrm{Al})_{2}$ Laves phase is evaluated to be between 0.96 and 1.17 , which is out of the range for the binary Laves phase criterion. This indicates that estimation of $\mathrm{D}_{\mathrm{B}}$ from the average atomic volumes of $\mathrm{B} 2$ aluminides is more suitable than that from the atomic volumes of pure elements. Here it should be noted that the VEC of Al-containing Laves phases shown in Table 5 is within 5.06.0, whereas those for a large amount of binary Laves phases are reported to be within $2.0-3.0$ or $5.3-7.7 .^{17)}$ According to the literature, Laves phases that contain Al exhibit rather low VECs, but almost within the stated range.

Further discussion based on the lattice geometry is required to examine the validity of the $\mathrm{D}_{\mathrm{B} \text { (XAl-obs) }}$ (C.N. 8) values estimated from $\mathrm{B} 2$ aluminides. Unless the atomic diameter ratio $D_{A} / D_{B}$ is 1.225 , A-site or B-site elements change their atomic size to minimize the total elastic energy in the Laves phase. ${ }^{20)}$ The deviation of the estimated average atomic volume from the actual average atomic volume of the $\mathrm{AB}_{2}$ Laves phase is defined as follows:

$$
\mathrm{V}_{\text {Laves }}=\mathrm{V}_{\mathrm{A}}+2 \mathrm{~V}_{\mathrm{B}}+\mathrm{V}_{\mathrm{AB}}
$$

where $\mathrm{V}_{\mathrm{A}}$ and $\mathrm{V}_{\mathrm{B}}$ are the atomic volumes of the $\mathrm{A}$ and $\mathrm{B}$ elements, respectively, and $\mathrm{V}_{\mathrm{AB}}$ is the deviation. The CALPHAD method and first-principles calculations were applied to the binary $\mathrm{C} 14$ phase to determine the difference between the actual average atomic volume and the weighted average of the atomic volume of the pure elements. ${ }^{43)}$ However, estimation of the interaction energy of Laves phase composed of all of the combinations of elements is difficult due to insufficient experimental information and a lack of first-principles calculations. Instead, the sizes of the

Table 4 Average atomic diameters of X-50Al (C.N. 8) as a B2 structure $\left(\mathrm{D}_{\mathrm{B}(\mathrm{XAl}-\mathrm{obs})}\right)$, the values estimated from those of the fcc structure $\left(\mathrm{D}_{\mathrm{B}(\mathrm{X}(\mathrm{Al}) \text {-obs })}\right)$ and the average values of the atomic diameters of pure elements $\left(\mathrm{D}_{\mathrm{B}(\mathrm{X} / \mathrm{Al}-\mathrm{obs})}\right)[\mathrm{nm}]$.

\begin{tabular}{cccccc}
\hline & $\mathrm{NiAl}$ & $\mathrm{CoAl}$ & $\mathrm{PdAl}$ & $\mathrm{RhAl}$ & $\mathrm{IrAl}$ \\
\hline \hline $\mathrm{D}_{\mathrm{B}(\mathrm{XAl}-\mathrm{obs})}$ & 0.249 & 0.248 & 0.264 & 0.258 & 0.258 \\
\hline $\mathrm{D}_{\mathrm{B}(\mathrm{X}(\mathrm{Al}) \text {-obs })}$ & 0.248 & 0.249 & 0.262 & 0.261 & 0.261 \\
\hline Difference & 0.001 & -0.001 & 0.002 & -0.003 & -0.003 \\
$\left(\mathrm{D}_{\mathrm{B}(\mathrm{XAl}-\mathrm{obs})}-\mathrm{D}_{\mathrm{B}(\mathrm{X}(\mathrm{Al}) \text {-obs })}\right)$ & $(0.5 \%)$ & $(-0.4 \%)$ & $(0.8 \%)$ & $(-1.1 \%)$ & $(-1.2 \%)$ \\
\hline \hline $\mathrm{D}_{\mathrm{B}(\mathrm{X} / \mathrm{Al}-\text { obs })}$ & 0.260 & 0.2605 & 0.2725 & 0.2695 & 0.2705 \\
\hline Difference & -0.011 & -0.013 & -0.008 & -0.011 & -0.013 \\
$\left(\mathrm{D}_{\mathrm{B} \text { (XAl-obs) }}-\mathrm{D}_{\mathrm{B}(\mathrm{X} / \mathrm{Al}-\text { obs })}\right)$ & $(-4.3 \%)$ & $(-5.1 \%)$ & $(-3.2 \%)$ & $(-4.4 \%)$ & $(-4.9 \%)$ \\
\hline
\end{tabular}


Table 5 Existence of Laves phase with respect to combinations of $\mathrm{A}$ and $\mathrm{B}$ with the ratio of average atomic diameter $\mathrm{D}_{\mathrm{A}} / \mathrm{D}_{\mathrm{B}}$ and the $\mathrm{VEC}$ given in parentheses. ${ }^{39-42)}$ 'No phase diagram' means there is no information regarding the equiatomic composition of the three elements.

\begin{tabular}{|c|c|c|c|c|c|c|c|c|c|c|c|c|}
\hline 1 & $\mathrm{CoAl}$ & $\mathrm{NiAl}$ & $\mathrm{Cr}$ & $\mathrm{FeAl}$ & $\mathrm{RhAl}$ & IrAl & $\mathrm{RuAl}$ & V & $\mathrm{PdAl}$ & PtAl & Mo & $\mathrm{ScAl}$ \\
\hline $\mathrm{Cr}$ & $\begin{array}{l}1.01 \\
(6.0)\end{array}$ & $\begin{array}{l}1.00 \\
(6.3)\end{array}$ & - & $\begin{array}{l}0.99 \\
(5.7)\end{array}$ & $\begin{array}{l}0.97 \\
(6.0)\end{array}$ & $\begin{array}{l}0.97 \\
(6.0)\end{array}$ & $\begin{array}{l}0.96 \\
(5.7)\end{array}$ & $\begin{array}{l}0.95 \\
(5.3)\end{array}$ & $\begin{array}{l}0.95 \\
(6.3)\end{array}$ & $\begin{array}{l}0.94 \\
(6.3)\end{array}$ & $\begin{array}{l}0.92 \\
(6.0)\end{array}$ & $\begin{array}{l}0.84 \\
(4.0)\end{array}$ \\
\hline $\mathrm{V}$ & $\begin{array}{l}1.06 \\
(5.7)\end{array}$ & $\begin{array}{l}1.05 \\
(6.0)\end{array}$ & $\begin{array}{r}1.05 \\
(5.7)\end{array}$ & $\begin{array}{l}1.04 \\
(5.3)\end{array}$ & $\begin{array}{l}1.02 \\
(5.7)\end{array}$ & $\begin{array}{l}1.01 \\
(5.7)\end{array}$ & $\begin{array}{l}1.01 \\
(5.3)\end{array}$ & - & $\begin{array}{l}0.99 \\
(6.0)\end{array}$ & $\begin{array}{r}0.98 \\
(6.0)\end{array}$ & $\begin{array}{l}0.96 \\
(5.7)\end{array}$ & $\begin{array}{l}0.88 \\
(3.7)\end{array}$ \\
\hline Mo & $\begin{array}{l}1.10 \\
(6.0)\end{array}$ & $\begin{array}{l}1.09 \\
(6.3)\end{array}$ & $\begin{array}{r}1.09 \\
(6.0)\end{array}$ & $\begin{array}{l}1.08 \\
(5.7)\end{array}$ & $\begin{array}{l}1.06 \\
(6.0)\end{array}$ & $\begin{array}{l}1.05 \\
(6.0)\end{array}$ & $\begin{array}{l}1.05 \\
(5.7)\end{array}$ & $\begin{array}{l}1.04 \\
(5.3)\end{array}$ & $\begin{array}{l}1.03 \\
(6.3)\end{array}$ & $\begin{array}{l}1.02 \\
(6.3)\end{array}$ & - & $\begin{array}{l}0.92 \\
(4.0)\end{array}$ \\
\hline W & $\begin{array}{l}1.10 \\
(6.0)\end{array}$ & $\begin{array}{l}1.10 \\
(6.3)\end{array}$ & $\begin{array}{r}1.10 \\
(6.0)\end{array}$ & $\begin{array}{l}1.09 \\
(5.7)\end{array}$ & $\begin{array}{l}1.06 \\
(6.0)\end{array}$ & $\begin{array}{l}1.06 \\
(6.0)\end{array}$ & $\begin{array}{l}1.05 \\
(5.7)\end{array}$ & $\begin{array}{r}1.05 \\
(5.3)\end{array}$ & $\begin{array}{l}1.04 \\
(6.3)\end{array}$ & $\begin{array}{l}1.03 \\
(6.3)\end{array}$ & $\begin{array}{l}1.01 \\
(6.0)\end{array}$ & $\begin{array}{l}0.92 \\
(4.0)\end{array}$ \\
\hline $\mathrm{Nb}$ & $\begin{array}{l}1.15 \\
(5.7)\end{array}$ & $\begin{array}{l}1.15 \\
(6.0)\end{array}$ & $\begin{array}{l}1.14 \\
(5.7)\end{array}$ & $\begin{array}{l}1.13 \\
(5.3)\end{array}$ & $\begin{array}{l}1.11 \\
(5.7)\end{array}$ & $\begin{array}{l}1.11 \\
(5.7)\end{array}$ & $\begin{array}{l}1.10 \\
(5.3)\end{array}$ & $\begin{array}{l}1.09 \\
(5.0)\end{array}$ & $\begin{array}{l}1.08 \\
(6.0)\end{array}$ & $\begin{array}{r}1.07 \\
(6.0)\end{array}$ & $\begin{array}{l}1.05 \\
(5.7)\end{array}$ & $\begin{array}{l}0.96 \\
(3.7)\end{array}$ \\
\hline $\mathrm{Ta}$ & $\begin{array}{l}1.15 \\
(5.7)\end{array}$ & $\begin{array}{l}1.15 \\
(6.0)\end{array}$ & $\begin{array}{l}1.14 \\
(5.7)\end{array}$ & $\begin{array}{l}1.13 \\
(5.3)\end{array}$ & $\begin{array}{l}1.11 \\
(5.7)\end{array}$ & $\begin{array}{l}1.11 \\
(5.7)\end{array}$ & $\begin{array}{l}1.10 \\
(5.3)\end{array}$ & $\begin{array}{l}1.09 \\
(5.0)\end{array}$ & $\begin{array}{l}1.08 \\
(6.0)\end{array}$ & $\begin{array}{r}1.07 \\
(6.0)\end{array}$ & $\begin{array}{l}1.05 \\
(5.7)\end{array}$ & $\begin{array}{l}0.96 \\
(3.7)\end{array}$ \\
\hline $\mathrm{Ti}$ & $\begin{array}{l}1.17 \\
(5.3)\end{array}$ & $\begin{array}{l}1.16 \\
(5.7)\end{array}$ & $\begin{array}{l}1.16 \\
(5.3)\end{array}$ & $\begin{array}{l}1.15 \\
(5.0)\end{array}$ & $\begin{array}{l}1.12 \\
(5.3)\end{array}$ & $\begin{array}{l}1.12 \\
(5.3)\end{array}$ & $\begin{array}{l}1.11 \\
(5.0)\end{array}$ & $\begin{array}{l}1.11 \\
(4.7)\end{array}$ & $\begin{array}{l}1.10 \\
(5.7)\end{array}$ & $\begin{array}{l}1.09 \\
(5.7)\end{array}$ & $\begin{array}{l}1.06 \\
(5.3)\end{array}$ & $\begin{array}{l}0.97 \\
(3.3)\end{array}$ \\
\hline $\mathrm{Hf}$ & $\begin{array}{l}1.26 \\
(5.3)\end{array}$ & $\begin{array}{l}1.25 \\
(5.7)\end{array}$ & $\begin{array}{l}1.25 \\
(5.3)\end{array}$ & $\begin{array}{l}1.24 \\
(5.0)\end{array}$ & $\begin{array}{l}1.21 \\
(5.3)\end{array}$ & $\begin{array}{l}1.21 \\
(5.3)\end{array}$ & $\begin{array}{l}1.20 \\
(5.0)\end{array}$ & $\begin{array}{l}1.19 \\
(4.7)\end{array}$ & $\begin{array}{l}1.18 \\
(5.7)\end{array}$ & $\begin{array}{l}1.17 \\
(5.7)\end{array}$ & $\begin{array}{l}1.15 \\
(5.3)\end{array}$ & $\begin{array}{l}1.05 \\
(3.3)\end{array}$ \\
\hline $\mathrm{Zr}$ & $\begin{array}{l}1.28 \\
(5.3)\end{array}$ & $\begin{array}{l}1.27 \\
(5.7)\end{array}$ & $\begin{array}{l}1.27 \\
(5.3)\end{array}$ & $\begin{array}{l}1.26 \\
(5.0)\end{array}$ & $\begin{array}{l}1.23 \\
(5.3)\end{array}$ & $\begin{array}{l}1.23 \\
(5.3)\end{array}$ & $\begin{array}{l}1.22 \\
(5.0)\end{array}$ & $\begin{array}{r}1.21 \\
(4.7)\end{array}$ & $\begin{array}{l}1.20 \\
(5.7)\end{array}$ & $\begin{array}{l}1.19 \\
(5.7)\end{array}$ & $\begin{array}{l}1.17 \\
(5.3)\end{array}$ & $\begin{array}{l}1.07 \\
(3.3)\end{array}$ \\
\hline
\end{tabular}

\section{No Laves}

\section{Stoichiometric Laves}

Non-stoichiometric Laves

No phase diagram

component atoms in multi-component Laves phase are evaluated based on geometrical explanations for the contraction and expansion of the constituent atoms. According to Edwards, ${ }^{31)}$ when a stacking structure of Laves phase is visualized by mutual stacking of an A metal layer and a B metal layer, the mean closest distances of $\mathrm{A}-\mathrm{A}, \mathrm{d}_{\mathrm{A}(\mathrm{g})}$, and $\mathrm{B}-\mathrm{B}, \mathrm{d}_{\mathrm{B}(\mathrm{g})}$, are expressed as functions of $\mathrm{D}_{\mathrm{A}}($ C.N. 8) and $\mathrm{D}_{\mathrm{B}}$ (C.N. 12).

$$
\begin{aligned}
& \mathrm{d}_{\mathrm{A}(\mathrm{g})}=\frac{4 \mathrm{D}_{\mathrm{A}}(\mathrm{C} . \mathrm{N} .8)+9.8 \mathrm{D}_{\mathrm{B}}(\mathrm{C} . \mathrm{N} .12)}{12} \\
& \mathrm{~d}_{\mathrm{B}}(\mathrm{g})=\frac{4 \mathrm{D}_{\mathrm{A}}(\mathrm{C} \cdot \mathrm{N} .8)+9.8 \mathrm{D}_{\mathrm{B}}(\mathrm{C} . \mathrm{N} .12)}{14.7}
\end{aligned}
$$

Equations (2) and (3) can respectively be rewritten in the lat- tice contraction forms.

$$
\begin{aligned}
& \frac{\mathrm{D}_{A}(\mathrm{C} . \mathrm{N} .8)}{d_{\mathrm{A}}(\mathrm{g})}=\frac{12 \times\left(\mathrm{D}_{\mathrm{A}}(\mathrm{C} . \mathrm{N} .8) / \mathrm{D}_{\mathrm{B}}(\mathrm{C} . \mathrm{N} .12)\right)}{4 \times\left(\mathrm{D}_{\mathrm{A}}(\mathrm{C} . \mathrm{N} .8) / \mathrm{D}_{\mathrm{B}}(\mathrm{C} . \mathrm{N} .12)\right)+9.8} \\
& \frac{\mathrm{D}_{\mathrm{B}}(\mathrm{C} . \mathrm{N} .12)}{\mathrm{d}_{\mathrm{B}(\mathrm{g})}}=\frac{14.7}{4 \times\left(\mathrm{D}_{\mathrm{A}}(\mathrm{C} . \mathrm{N} .8) / \mathrm{D}_{\mathrm{B}}(\mathrm{C} . \mathrm{N} .12)\right)+9.8}
\end{aligned}
$$

When $D_{A} / D_{B}$ is an ideal Laves phase value of 1.225 , both $\mathrm{D}_{\mathrm{A}} / \mathrm{d}_{\mathrm{A}(\mathrm{g})}$ and $\mathrm{D}_{\mathrm{B}} / \mathrm{d}_{\mathrm{B}(\mathrm{g})}$ are unity, and each element in the Laves phase neither expands nor contracts. $D_{A} / d_{A(g)}$ greater than unity indicates contractions of the $\mathrm{A}$ atoms in the Laves phase, while $\mathrm{D}_{\mathrm{A}} / \mathrm{d}_{\mathrm{A}(\mathrm{g})}$ less than unity indicates expansion.

Most of the Laves phases do not have an ideal $D_{A} / D_{B}$; therefore, the distance of $\mathrm{B}-\mathrm{B}$ has several variations because there are two types of sites for B elements, $2 \mathrm{a}$ and $6 \mathrm{~h}$. 
Therefore, the distance of $\mathrm{B}-\mathrm{B}, \mathrm{d}_{\mathrm{B}(\mathrm{obs})}$, should be estimated as a weighted average of the $2 \mathrm{a}-6 \mathrm{~h}$ and $6 \mathrm{~h}-6 \mathrm{~h}$ distances (no first-nearest-neighbor relationship between atoms that both occupy $2 \mathrm{a}$ sites). A broad survey of the atomic positions in various Laves phases enables the experimentally determined mean closest distances of $\mathrm{A}-\mathrm{A}, \mathrm{d}_{\mathrm{A}(\mathrm{obs})}$, and $\mathrm{B}-\mathrm{B}, \mathrm{d}_{\mathrm{B}(\mathrm{obs})}$, to be evaluated. Evaluation of $\mathrm{d}_{\mathrm{A}(\mathrm{obs})}$ and $\mathrm{d}_{\mathrm{B}(\mathrm{obs})}$ is conducted with stoichiometric $\mathrm{A}(\mathrm{X}, \mathrm{Al})_{2}$ ternary Laves phases (X: elements forming B2 compounds with $\mathrm{Al}$, such as $\mathrm{Ni}, \mathrm{Co}, \mathrm{Fe}, \mathrm{Ir}$, and $\mathrm{Rh}$ ) shown in Table 5 as 'Stoichiometric Laves' to verify the use of $\mathrm{D}_{\mathrm{B} \text { (XAl-obs) }}$ (C.N. 8) estimated from the lattice constant of $\mathrm{B} 2$ aluminides, instead of $\mathrm{D}_{\mathrm{B}}(\mathrm{C} . \mathrm{N}$. 8) estimated by averaging the Goldschmidt radii of elements that occupy $\mathrm{B}$-sites by comparison of $\mathrm{D}_{\mathrm{A}} / \mathrm{d}_{\mathrm{A}}$ and $\mathrm{D}_{\mathrm{B}} / \mathrm{d}_{\mathrm{B}}$ with $\mathrm{D}_{\mathrm{A}} / \mathrm{d}_{\mathrm{A}(\mathrm{g})}$ and $\mathrm{D}_{\mathrm{B}} /$ $\mathrm{d}_{\mathrm{B}(\mathrm{g})}$ estimated using eqs. (4) and (5). ${ }^{39)}$

Figure 7 shows the results of the comparison. Two types of $\mathrm{D}_{\mathrm{A}} / \mathrm{d}_{\mathrm{A}(\mathrm{obs})}$ and $\mathrm{D}_{\mathrm{B}} / \mathrm{d}_{\mathrm{B}(\mathrm{obs})}$ are plotted against $\mathrm{D}_{\mathrm{A}} / \mathrm{D}_{\mathrm{B}}$. The curves show the lattice contraction based on the geometrical model, $\mathrm{D}_{\mathrm{A}} / \mathrm{d}_{\mathrm{A}(\mathrm{g})}$ and $\mathrm{D}_{\mathrm{B}} / \mathrm{d}_{\mathrm{B}(\mathrm{g})}$ estimated from eqs. (4) and (5), respectively, and the actual contraction $\mathrm{D} / \mathrm{d}_{(\mathrm{obs})}$, can be compared by plotting against the ratio of the average atomic diameter, $\mathrm{D}_{\mathrm{A}} / \mathrm{D}_{\mathrm{B}}$. For various stoichiometric $\mathrm{A}(\mathrm{X}, \mathrm{Al})_{2}$ ternary Laves phases, the adequacy of using the average atomic diameter of XAl-B2 $\mathrm{D}_{\mathrm{B} \text { (XAl-obs) }}$, as the $\mathrm{D}_{\mathrm{B}}$ value was tested by comparison with that using the average atomic diameter

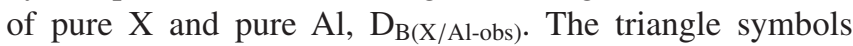

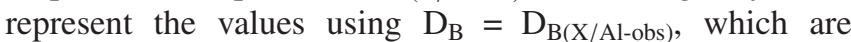
greater than the curves using $\mathrm{D}_{\mathrm{A}} / \mathrm{d}_{\mathrm{A}(\mathrm{g})}$ and $\mathrm{D}_{\mathrm{B}} / \mathrm{d}_{\mathrm{B}(\mathrm{g})}$ obtained from the geometrical model, whereas the circle symbols represent the values using the $\mathrm{D}_{\mathrm{B}}$ value estimated as $\mathrm{D}_{\mathrm{B} \text { (XAl-obs) }}$, which shows good agreement with the curves. Therefore, the geometrical properties of a Laves phase composed of equiatomic $\mathrm{X}$ and $\mathrm{Al}$ could be argued using the $\mathrm{D}_{\mathrm{B}}$ value estimated from the average atomic diameters of $\mathrm{B} 2$ in the A-X-Al system.

In terms of the elements that occupy B-sites in the Laves phases in the $\mathrm{Nb}-\mathrm{Cr}-\mathrm{NiAl}$ and $\mathrm{Nb}-\mathrm{V}-\mathrm{NiAl}$ systems, let us compare $\mathrm{D}_{\mathrm{B}}$ for NiAl-B2, a highly ordered bcc compound, and $\mathrm{D}_{\mathrm{B}}$ for the bcc elements $\mathrm{Cr}$ and $\mathrm{V}$ (Fig. 8). The atomic diameter of $\mathrm{Cr}$ is as small as that of NiAl-B2, which may result in a substitution of $\mathrm{Cr}$ on $\mathrm{B}$-sites in $\mathrm{Nb}(\mathrm{Ni}, \mathrm{Al})_{2}$, as confirmed by the direction of the solubility lobe of the Laves phase in Nb-Cr-NiAl (Fig. 5(a)). Moreover, the constant $\mathrm{D}_{\mathrm{A}}$ /
$\mathrm{D}_{\mathrm{B}}$, regardless of $\mathrm{Cr}$ substitution for $\mathrm{B}$-sites of the $\mathrm{Nb}(\mathrm{Ni}, \mathrm{Al})_{2}$ Laves phase is considered to maintain the stability sufficiently high to appear as a stable phase. In the case of the $\mathrm{Nb}-\mathrm{V}-\mathrm{NiAl}$ system, there are two conceivable substitution or defect behaviors that cause the direction of the solubility lobe of the $\mathrm{C} 14$ phase to be only slightly deviated toward the $\mathrm{V}$ corner from the Nb-constant line (Fig. 5(b)). One is the occurrence of vacancies in A-sites and $\mathrm{V}$ substitution for $\mathrm{B}$-sites in $\mathrm{Nb}(\mathrm{Ni}, \mathrm{Al})_{2}-\mathrm{C} 14$. The other is $\mathrm{V}$ substitution for both $\mathrm{A}$-sites and $\mathrm{B}$-sites in $\mathrm{Nb}(\mathrm{Ni}, \mathrm{Al})_{2}-\mathrm{C} 14$. The latter is a more likely explanation because, according to Stein et al., ${ }^{17)}$ reported defects that exist in non-stoichiometric Laves phases are anti-site substitution of either site, or vacancies of $\mathrm{B}$-sites, but not vacancies in A-sites. The atomic diameter of $\mathrm{V}$, which is between that of NiAl-B2 and $\mathrm{Nb}$, may be the reason why $\mathrm{V}$ substitutes for both sites in $\mathrm{Nb}(\mathrm{Ni}, \mathrm{Al})_{2}-\mathrm{C} 14$. On the other hand, the reported $\mathrm{Nb}-\mathrm{Mo}-\mathrm{NiAl}$ isothermal section shows the preferential substitution of Mo on A-sites in $\mathrm{Nb}(\mathrm{Ni}, \mathrm{Al})_{2}-\mathrm{C} 14^{16)}$ because the diameter of Mo is larger than that of V. Similar relationships between the site occupancy behavior in the $\mathrm{Ta}(\mathrm{Ni}, \mathrm{Al})_{2}$ Laves phase and the diameters of additional elements ( $\mathrm{Cr}, \mathrm{V}$ and $\mathrm{Mo}$ ) have been found in Ta$\mathrm{Cr}-\mathrm{NiAl}$, Ta-V-NiAl, and Ta-Mo-NiAl isothermal sections. It can be concluded that the tendency of the site occupancy can be explained not only for ternary Laves phases but also for quaternary Laves phases that include $\mathrm{Ni}$ and $\mathrm{Al}$, by taking the average atomic size of NiAl-B2 into account.

In this study, the site-substitution behavior of $\mathrm{Cr}, \mathrm{V}$, and Mo in the $\mathrm{Nb}(\mathrm{Ni}, \mathrm{Al})_{2}-\mathrm{C} 14$ phase and the phase stability could be argued by comparison of the average atomic diam-

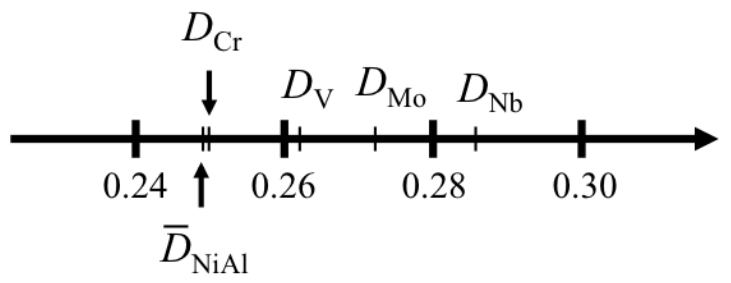

Atomic diameter $D($ C. N. 8), nm

Fig. 8 Average atomic diameters of bcc elements (C.N. 8) and NiAl (C.N 8) estimated from the lattice constant $a$ of each element. D(C.N. 8) = $a \sqrt{3} / 2$.

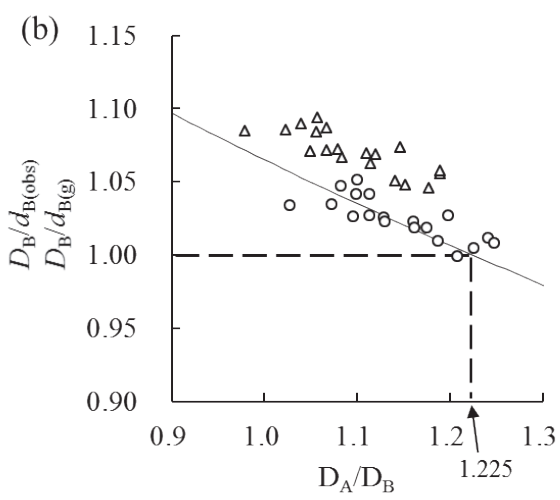

Fig. 7 Lattice contractions $D / d$ as a function of the ratio of average atomic diameters $D_{\mathrm{A}} / D_{\mathrm{B}}$ in Laves phases in terms of (a) A-site elements and (b) B-site elements. Circles: average atomic diameters in B2 compounds, $D_{\mathrm{B}(\mathrm{XAl}-\mathrm{obs})}$ as $D_{\mathrm{B}}$. Triangles: average atomic diameters in pure $\mathrm{X}$ and $\mathrm{Al}$ elements, $D_{\mathrm{B}(\mathrm{X} / \mathrm{Al}-\mathrm{obs})}$ as $D_{\mathrm{B}}$. Curves represent $D / d_{\text {(g) }}$ obtained from the geometrical model proposed by Edwards. ${ }^{31)}$ 
eter of NiAl-B2 and the atomic diameters of Cr, V, and Mo, based on the substitution of $\mathrm{Ni}$ and $\mathrm{Al}$ for $2 \mathrm{a}$ and $6 \mathrm{~h}$ sites with equal probability in the stoichiometric $\mathrm{Nb}(\mathrm{Ni}, \mathrm{Al})_{2}-\mathrm{C} 14$ phase. However, because the site preference of $\mathrm{Ni}$ and $\mathrm{Al}$ for $2 \mathrm{a}$ and $6 \mathrm{~h}$ sites is composition-dependent, the $\mathrm{Nb}(\mathrm{Ni}, \mathrm{Al})_{2}-$ $\mathrm{C} 14$ phase with a non-equiatomic composition of $\mathrm{Ni}$ and $\mathrm{Al}$ does not have equal probability of substitution for them at each site, which indicates that further consideration is required for evaluation of the size factor in non-stoichiometric C14 phases. $^{37)}$

\section{Concluding Remarks}

The phase equilibria among $\mathrm{bcc}_{\mathrm{ss}} / \mathrm{B} 2 / \mathrm{C} 14$ in the $\mathrm{Nb}-\mathrm{Cr}-$ $\mathrm{NiAl}$ and the $\mathrm{Nb}-\mathrm{V}-\mathrm{NiAl}$ sections of the quaternary systems were investigated. In the $\mathrm{Nb}-\mathrm{Cr}-\mathrm{NiAl}$ system, the direction of the solubility lobe of the $\mathrm{C} 14$ phase extends along a line of $\mathrm{Nb}(\mathrm{Ni}, \mathrm{Al})_{2}-\mathrm{NbCr}_{2}$. On the other hand, in the $\mathrm{Nb}-\mathrm{V}-\mathrm{NiAl}$ system, the solubility lobe of the $\mathrm{C} 14$ phase deviates slightly toward the $\mathrm{V}$ corner from the line connecting $\mathrm{Nb}(\mathrm{Ni}, \mathrm{Al})_{2}$ and hypothetical " $\mathrm{NbV}_{2}$ ". These solubility lobes could be explained by comparison of the average atomic diameters of $\mathrm{NiAl}-\mathrm{B} 2, \mathrm{Cr}$ and $\mathrm{V}$, which was confirmed by the geometrical model proposed by Edwards. ${ }^{31)}$ The similarity of the average atomic diameter of $\mathrm{NiAl}$ and the diameter of $\mathrm{Cr}$ explains the site-substitution behavior of $\mathrm{Cr}$ for $\mathrm{Nb}(\mathrm{Ni}, \mathrm{Al})_{2}-\mathrm{C} 14$. The diameter of $\mathrm{V}$ is rather larger than the average diameter of $\mathrm{NiAl}$ but smaller than $\mathrm{Nb}$; therefore, $\mathrm{V}$ substitutes not only on B-sites but also on A-sites. These experimental results together with information on other reported ternary Laves phases strongly suggests that the average atomic size of elements that occupy B-sites such as $\mathrm{Ni}$ and $\mathrm{Al}$ in $\mathrm{Nb}(\mathrm{Ni}, \mathrm{Al})_{2}$ Laves phase should be estimated from the lattice constant of the B2 phase composed of B-site-occupying elements such as $\mathrm{NiAl}$.

\section{Acknowledgments}

This work was supported by the Advanced Low Carbon Technology R\&D (ALCA) program of the Japan Science and Technology Agency (JST). A part of this work was conducted at the Laboratory of Nano-Micro Materials Analysis, Hokkaido University, supported by the "Nanotechnology Platform" Program of the Ministry of Education, Culture, Sports, Science and Technology (MEXT), Japan. The authors thank Mr. N. Miyazaki at Hokkaido University for helpful discussions and technical assistance with the WDS analysis.

\section{Nomenclature}

$\begin{array}{ll}\mathrm{R}_{\mathrm{C} . \mathrm{N} .12} & \text { Goldschmidt radius }(\mathrm{nm}) \\ \mathrm{D}_{\mathrm{C} . \mathrm{N} .12} & \text { Goldschmidt diameter }(\mathrm{nm}) \\ \mathrm{D}_{\mathrm{A}}(\text { C.N.8) } & \text { atomic diameter (C.N. 8) of pure A }(\mathrm{nm}) \\ \mathrm{D}_{\mathrm{B}}(\text { C.N.12) } & \text { atomic diameter (C.N. 12) of pure B }(\mathrm{nm}) \\ \mathrm{d}_{\mathrm{A}(\mathrm{g})} & \text { mean closest distance of A-A in Laves phase } \\ & \text { from the geometrical model by Edwards }(\mathrm{nm}) \\ \mathrm{d}_{\mathrm{A}(\mathrm{obs})} & \text { mean closest distance of A-A in Laves phase } \\ & \text { from Pearson's Crystal Data (nm) } \\ \mathrm{d}_{\mathrm{B}(\mathrm{g})} & \text { mean closest distance of B-B in Laves phase }\end{array}$

from the geometrical model by Edwards (nm) $\mathrm{d}_{\mathrm{B}(\mathrm{obs})} \quad$ mean closest distance of $\mathrm{B}-\mathrm{B}$ in Laves phase from Pearson's Crystal Data (nm)

$\mathrm{V}_{\text {Laves }}$

$\mathrm{V}_{\mathrm{A}}$

$\mathrm{V}_{\mathrm{B}}$

$\mathrm{V}_{\mathrm{AB}}$

$\mathrm{V}_{\mathrm{Al}}$

$\mathrm{V}_{\mathrm{Al}}$

$\overline{\mathrm{V}}_{\mathrm{Ni}(\mathrm{Al})}$

$\overline{\mathrm{V}}_{\mathrm{NiAl}}$

$\mathrm{D}_{\mathrm{B}(\mathrm{Ni}(\mathrm{Al}) \text {-obs })}$

average atomic volume of Laves phase $\left(\mathrm{nm}^{3}\right)$ atomic volume of pure $\mathrm{A}\left(\mathrm{nm}^{3}\right)$

atomic volume of pure B $\left(\mathrm{nm}^{3}\right)$

difference between $V_{\text {Laves }}$ and $\left(\mathrm{V}_{\mathrm{A}}+2 \mathrm{~V}_{\mathrm{B}}\right)$ $\left(\mathrm{nm}^{3}\right)$

atomic volume of $\mathrm{Al}$ in $\mathrm{Ni}$ solid solution $\left(\mathrm{nm}^{3}\right)$

atomic volume of pure $\mathrm{Al}\left(\mathrm{nm}^{3}\right)$

average atomic volume of $\mathrm{Ni}_{0.5} \mathrm{Al}_{0.5}$ on an extrapolated line of $\mathrm{Ni}_{1-\mathrm{X}} \mathrm{Al}_{\mathrm{X}}\left(\mathrm{nm}^{3}\right)$

average atomic volume of NiAl-B2 $\left(\mathrm{nm}^{3}\right)$

average atomic diameter of $\mathrm{Ni}_{0.5} \mathrm{Al}_{0.5}$ estimated from $\overline{\mathrm{V}}_{\mathrm{Ni}(\mathrm{Al})}(\mathrm{nm})$

$\mathrm{D}_{\mathrm{B}(\mathrm{X}(\mathrm{Al}) \text {-obs) }}$ average atomic diameter of $\mathrm{X}_{0.5} \mathrm{Al}_{0.5}$ estimated from $\overline{\mathrm{V}}_{\mathrm{X}(\mathrm{Al})}(\mathrm{nm})$

$\mathrm{D}_{\mathrm{B} \text { (NiAl-obs) }}$ average atomic diameter of NiAl-B2 (nm)

$\mathrm{D}_{\mathrm{B} \text { (XAl-obs) }}$ average atomic diameter of XAl-B2 (nm)

$\mathrm{D}_{\mathrm{B} \text { (X/Al-obs) }}$ average atomic diameter of pure $\mathrm{X}$ and pure $\mathrm{Al}(\mathrm{nm})$

$\overline{\mathrm{V}}_{\mathrm{NbNiAl}-1} \quad$ weighted average atomic volume of pure $\mathrm{Nb}$ and NiAl-B2 $\left(\left(\mathrm{V}_{\mathrm{Nb}}+2 \overline{\mathrm{V}}_{\mathrm{NiAl}}\right) / 3\right)\left(\mathrm{nm}^{3}\right)$

$\overline{\mathrm{V}}_{\mathrm{NbNiAl}-2}$ average atomic volume of pure $\mathrm{Nb}$, pure $\mathrm{Ni}$ and pure $\mathrm{Al}\left(\left(\mathrm{V}_{\mathrm{Nb}}+\mathrm{V}_{\mathrm{Ni}}+\mathrm{V}_{\mathrm{Al}}\right) / 3\right)\left(\mathrm{nm}^{3}\right)$

$\overline{\mathrm{V}}_{\mathrm{NbNiAl}-3}$ experimental average atomic volume of stoichiometric $\mathrm{Nb}(\mathrm{Ni}, \mathrm{Al})_{2}-\mathrm{C} 14\left(\mathrm{~nm}^{3}\right)$

\section{REFERENCES}

1) S. Mathieu, S. Knittel, P. Berthod and M. Vilasi: Corros. Sci. 60 (2012) 181-192.

2) M.R. Jackson, B.P. Bewlay, R.G. Rowe, D.W. Skelly and H.A. Lipsitt: JOM 48 (1996) 39-44.

3) R. Smith: J. Less Common Met. 2 (1960) 191-206.

4) J. Cheng, S. Yi and J.S. Park: Intermetallics 23 (2012) 12-19.

5) Y. Matsumura, M. Fukumoto, S. Hayashi, A. Kasama, I. Iwanaga, R. Tanaka and T. Narita: Oxid. Met. 61 (2004) 105-124.

6) M. Fukumoto, Y. Matsumura, S. Hayashi, T. Narita, K. Sakamoto, A. Kasama and R. Tanaka: Mater. Trans. 44 (2003) 731-735.

7) G. Sauthoff: Intermetallics 8 (2000) 1101-1109.

8) Y. Du, Y.A. Chang, W. Gong, B. Huang, H. Xu, Z. Jin, F. Zhang and S.-L. Chen: Intermetallics 11 (2003) 995-1013.

9) V. Raghavan: J. Phase Equilibria Diffus. 27 (2006) 397-402.

10) V. Raghavan: J. Phase Equilibria Diffus. 27 (2006) 381-388.

11) V. Raghavan: J. Phase Equilibria Diffus. 27 (2006) 393-396.

12) G. Petzow and G. Effenberg: Ternary alloys. A comprehensive compendium of evaluated constitutional data and phase diagrams Vol. 8 (1993) pp. 49-57.

13) V. Raghavan: J. Phase Equilibria Diffus. 27 (2006) 413.

14) V. Raghavan: J. Phase Equilibria Diffus. 27 (2006) 417.

15) V. Raghavan: J. Phase Equilibria Diffus. 27 (2006) 416

16) S. Miura, Y. Sekito, T. Okawa, T. Yamanouchi and T. Mohri: Mater. Sci. Forum 783-786 (2014) 1171-1175.

17) F. Stein, M. Palm and G. Sauthoff: Intermetallics 12 (2004) 713-720.

18) F. Stein, M. Palm and G. Sauthoff: Intermetallics 13 (2005) 1056-1074.

19) D.J. Thoma and J.H. Perepezko: J. Alloy. Compd. 224 (1995) 330-341.

20) J.H. Zhu, C.T. Liu, L.M. Pike and P.K. Liaw: Metall. Mater. Trans., A 30 (1999) 1449-1452.

21) F. Chu, D.J. Thoma, P.G. Kotula, S. Gerstl, T.E. Mitchell, I.M. Anderson and J. Bentley: Acta Mater. 46 (1998) 1759-1769.

22) H. Okaniwa, D. Shindo, M. Yoshida and T. Takasugi: Acta Mater. 47 
(1999) 1987-1992.

23) V. Raghavan: J. Phase Equilibria Diffus. 27 (2006) 405-407.

24) J.-C. Zhao, M.R. Jackson and L.A. Peluso: J. Phase Equilibria Diffus. 25 (2004) 152-159.

25) Y. Du, S. Liu, Y.A. Chang and Y. Yang: Calphad 29 (2005) 140-148.

26) K. Huai, J. Guo, Q. Gao and R. Yang: Z. Metallk. 97 (2006) 59-63.

27) L. Tang, S. Li and S. Gong: Int. J. Mod. Phys. B 24 (2010) 2898-2903.

28) B. Zeumer and G. Sauthoff: Intermetallics 6 (1998) 451-460.

29) L.Z. Tang, Z.G. Zhang, S.S. Li and S.K. Gong: Trans. Nonferrous Met. Soc. China 20 (2010) 212-216.

30) M. Ellner, K. Kolatschek and B. Predel: J. Less Common Met. 170 (1991) 171-184.

31) A.R. Edwards: Metall. Trans. 3 (1972) 1365-1372.

32) D.L. Anton, D.M. Shah, D.N. Duhl and A.F. Giamei: JOM 41 (1989) 12-17.

33) D.R. Johnson, B.F. Oliver, R.D. Noebe and J.D. Whittenberger: Intermetallics 3 (1995) 493-503.
34) S.Miura and T. Horiuchi: to be submitted to J. Japan Inst. Met. Mater.

35) C.T. Liu, J.H. Zhu, M.P. Brady, C.G. McKamey and L.M. Pike: Intermetallics 8 (2000) 1119-1129.

36) H. Okamoto: J. Phase Equilib. 14 (1993) 534

37) X. Yan, A. Grytsiv, P. Rogl, H. Schmidt and G. Giester: Calphad 33 (2009) 11-16.

38) W. Hume-Rothery and G.V. Raynor: Proc. R. Soc. Lond. A 177 (1940) 27-37.

39) P. Villars and K. Cenzual: Pearson's Crystal Data, ASM International, Materials Park, Ohio, USA, Release 2014/15

40) V. Raghavan: J. phase equilib. diffus. 32 (2011) 237-240.

41) G. Petzow and G. Effenberg: Ternary alloys. A comprehensive compendium of evaluated constitutional data and phase diagrams Vol. 6 (1993) pp. 194-196.

42) G. Petzow and G. Effenberg: Ternary alloys. A comprehensive compendium of evaluated constitutional data and phase diagrams Vol. 8 (1993) pp. 187-190.

43) J.Y. Zhao, W. Liu and X.G. Lu: Calphad 50 (2015) 82-91. 